\title{
Cranium of an Eocene/Oligocene pheasant-sized galliform bird from western North America, with the description of a vascular autapomorphy of the Galliformes
}

\author{
Gerald Mayr $^{1}$ (D) James L. Goedert ${ }^{2} \cdot$ Renate Rabenstein $^{3}$
}

Received: 26 August 2021 / Revised: 4 October 2021 / Accepted: 4 October 2021 / Published online: 15 October 2021

(c) The Author(s) 2021

\begin{abstract}
We describe the fossil cranium of a pheasant-sized galliform land bird from latest Eocene or earliest Oligocene marine rocks of the Jansen Creek Member, Makah Formation (Washington State, USA), which is the only three-dimensionally preserved cranium of a Paleogene representative of the Galliformes. The specimen was freed from a hard calcareous nodule with dilute formic acid. Micro-computed tomography provided further osteological details and a virtual cranial endocast. The fossil exhibits a plesiomorphic temporal morphology, lacking an ossified aponeurosis zygomatica, a feature characterizing some extant Cracidae and most Odontophoridae and Phasianidae. Overall, the fossil is most similar to the skull of the Asian phasianid taxon Arborophila, but this resemblance may well be plesiomorphic for a more inclusive clade. Still, we consider it possible that the fossil represents an archaic member of the Phasianoidea, in which case it would be the earliest record of this taxon from the New World. The fossil exhibits a previously unnoticed cranial autapomorphy of galliforms, a foramen in the temporal region that enables the vena profunda to enter the braincase, for which the name foramen temporale venosum is here introduced. Consistently present in all studied extant galliform taxa and absent in all other extant birds, this foramen enables a vascular connection between the brain and the ophthalmic rete, the latter playing an important role in thermoregulation of the avian brain.
\end{abstract}

Keywords Aves $\cdot$ Evolution $\cdot$ Fossil birds $\cdot$ Makah Formation $\cdot$ Micro-computed tomography $\cdot$ Systematics

Communicated by F. Bairlein.

Gerald Mayr

Gerald.Mayr@senckenberg.de

James L. Goedert

jamesgoedert@outlook.com

Renate Rabenstein

Renate.Rabenstein@senckenberg.de

1 Ornithological Section, Senckenberg Research Institute and Natural History Museum Frankfurt, Senckenberganlage 25, D-60325 Frankfurt am Main, Germany

2 Burke Museum of Natural History and Culture, University of Washington, Box 353010, Seattle, WA 98195, USA

3 Department of Messel Research and Mammalogy, Senckenberg Research Institute and Natural

History Museum Frankfurt, Senckenberganlage 25,

D-60325 Frankfurt am Main, Germany 


\section{Zusammenfassung}

Schädel eines fasanengroßen Hühnervogels aus dem Eozän/Oligozän des westlichen Nordamerikas, mit der Beschreibung einer Autapomorphie des Gefäßsystems der Galliformes

Wir beschreiben den Schädel eines fasanengroßen Hühnervogels aus dem späten Eozän oder frühen Oligozän der MakahFormation (Washington State, USA). Das Fossil ist der einzige dreidimensional erhaltene Schädel eines Vertreters der Galliformes aus dem Paläogen. Der Schädel wurde mit verdünnter Ameisensäure aus einer harten Kalkkonkretion gelöst. Mikro-Computertomographie lieferte zusätzliche osteologische Details und einen virtuellen Ausguss des Hirnschädels. Der Schläfenbereich des fossilen Schädels weist eine plesiomorphe Morphologie auf, da ihm eine verknöcherte Aponeurosis zygomatica fehlt; diese Aponeurosis ist kennzeichnend für einige der rezenten Cracidae und für die meisten Odontophoridae und Phasianidae. Insgesamt ist das Fossil dem Schädel des asiatischen Taxons Arborophila (Phasianidae) am ähnlichsten, aber diese Übereinstimmungen sind wahrscheinlich plesiomorph. Dennoch halten wir es für möglich, dass es sich bei dem Fossil um einen Vertreter der Phasianiodea handelt, wobei es dann der älteste Vertreter dieses Taxons in der Neuen Welt wäre. Der fossile Schädel zeigt ein für Hühnervögel bislang unbemerkt gebliebenes apomorphes Merkmal, nämlich ein Foramen im Schläfenbereich, durch das die Vena profunda in den Hirnschädel eintritt. Dieses Foramen ist bei allen untersuchten Taxa der rezenten Galliformes vorhanden und fehlt bei allen anderen heutigen Vögeln. Das Foramen - für das der Name Foramen temporale venosum eingeführt wird—stellt eine Gefäßverbindung zwischen dem Gehirn und dem Rete ophthalmicum dar, wobei letztere Struktur eine wichtige Rolle bei der Thermoregulation des Vogelhirnes spielt.

\section{Introduction}

Extant Galliformes (landfowl) include the Australasian Megapodiidae (megapodes or mound-builders), the Neotropic Cracidae (chachalacas, guans, and currasows), the African Numididae (guineafowl), the New World Odontophoridae (New World quail), and the globally distributed Phasianidae (quail, pheasants, and allies). The Numididae, Odontophoridae, and Phasianidae form the clade Phasianoidea, the sister taxon of which are the Cracidae. The Megapodiidae are the earliest diverging taxon of crown group Galliformes.

Galliforms have a fairly comprehensive Paleogene fossil record from Europe, but fossils from the New World are scarce (Mayr 2009). Gallinuloides wyomingensis from the early Eocene Green River Formation in Wyoming is based on complete skeletons and belongs to the Gallinuloididae, which constitute the earliest diverging Cenozoic galliform taxon known so far (Mayr and Weidig 2004). A small middle Eocene stem group galliform from Utah is represented by a partial coracoid and was assigned to the taxon Paraortygidae (Stidham et al. 2020). Another small galliform from the late Eocene (Chadronian) of Canada, known from a fragmentary coracoid as well as a distal tarsometatarsus, was described as Nanortyx inexpectatus by Weigel (1963). Assignment of this latter species to crown group Galliformes, viz. the Odontophoridae, is not well based (Mayr 2009).

Various larger sized Paleogene galliform birds from North America were described from the late Eocene and early Oligocene of South Dakota and Nebraska. The best represented of these is Procrax brevipes, which is based on a partial skeleton from the late Eocene Chadron Formation of South Dakota (Tordoff and MacDonald 1957). Two further similar-sized species, Archaealectrornis sibleyi and Palaeonossax senectus from the early Oligocene Brule Formation of Nebraska and South Dakota, respectively, are only represented by isolated humeri (Wetmore 1956; Crowe and Short 1992). The affinities of these species are poorly resolved. Originally, they were assigned to the Cracidae (Procrax and Palaeonossax) and Gallinuloididae (Archaealectrornis), but neither classification is well based and detailed comparisons with Paleogene stem group Galliformes from Europe have not yet been performed (Mayr 2009).

Here we describe the skull of a pheasant-sized galliform discovered in marine sediments of the latest Eocene or earliest Oligocene (about 34 million years ago) Jansen Creek Member, Makah Formation, from the Olympic Peninsula in Washington State, USA. The Jansen Creek Member has yielded abundant remains of the Plotopteridae - large, flightless divers - as well as a few other marine birds (Goedert and Cornish 2002; Mayr 2015; Mayr et al. 2015; Mayr and Goedert 2016, 2018, 2021). The new specimen is the first land bird found in the Makah Formation and the only threedimensionally preserved skull of a Paleogene galliform bird. We, furthermore, report a previously unrecognized vascular character, which represents a cranial autapomorphy of Galliformes and is likely to be physiological significance in the living species.

\section{Materials and methods}

Institutional abbreviations: SMF, Senckenberg Research Institute, Frankfurt, Germany; UWBM, Burke Museum of Natural History and Culture, University of Washington, Seattle, USA.

Anatomical terminology follows Baumel et al. (1993). In addition to comparisons with all extant avian higher level taxa, the skulls of the following galliform species 
were examined in the collection of SMF (nomenclature and family-level classification follow the IOC World Bird List at https://www.worldbirdnames.org): Megapodiidae: Alectura lathami; Cracidae: Crax alector, Crax daubentoni, Crax globulosa, Crax rubra, Mitu salvini, Nothocrax urumutum, Ortalis canicollis, Pauxi, Penelope marail, Penelope obscura, Penelope superciliaris, Pipile jacutinga, Pipile nattereri; Numididae: Acryllium vulturinum, Guttera edouardi, Guttera pucherani, Numida meleagris; Odontophoridae: Callipepla californica, Callipepla douglasii, Callipepla gambelii, Callipepla squamata, Colinus cristatus, Colinus virginianus, Odontophorus capueira, Oreortyx picta, Ptilopachus petrosus; Phasianidae: Afropavo congensis, Alectoris barbara, Alectoris chukar, Alectoris graeca, Alectoris philbyi, Alectoris rufa, Ammoperdix griseogularis, Ammoperdix heyi, Arborophila brunneopectus, Arborophila gingica, Arborophila javanica, Arborophila torqueola, Argusianus argus, Bambusicola fytchii, Bambusicola thoracica, Bonasa umbellus, Catreus wallichii, Chrysolophus amherstiae, Chrysolophus pictus, Coturnix australis, Coturnix coromandelica, Coturnix coturnix, Coturnix delegorguei, Coturnix japonica, Crossoptilon auritum, Crossoptilon crossoptilon, Crossoptilon mantchuricum, Dendragapus obscurus, Excalfactoria chinensis, Falcipennis canadensis, Falcipennis falcipennis, Francolinus francolinus, Francolinus pondericianus, Gallus gallus, Gallus lafayettei, Gallus sonneratii, Gallus varius, Ithaginis cruentus, Lagopus lagopus, Lagopus mutus, Lophophorus impejanus, Lophophorus lhuysii, Lophura bulweri, Lophura diardi, Lophura edwardsi, Lophura erythrophthalma, Lophura ignita, Lophura inornata, Lophura leucomelanos, Lophura nycthemera, Lophura swinhoii, Lyrurus mlokosiewiczi, Lyrurus tetrix, Margaroperdix madagascariensis, Melanoperdix nigra, Meleagris gallopavo, Meleagris ocellata, Pavo cristatus, Pavo muticus, Peliperdix albogularis, Peliperdix coqui, Peliperdix lathami, Perdicula asiatica, Perdix dauuricae, Perdix perdix, Phasianus colchicus, Phasianus versicolor, Polyplectron bicalcaratum, Polyplectron inopinatum, Polyplectron malacense, Polyplectron napoleonis, Pucrasia macrolopha, Pternistis afer, Pternistis ahantensis, Pternistis bicalcaratus, Pternistis capensis, Pternistis erckelii, Pternistis leucoscepus, Pternistis squamatus, Rollulus rouloul, Scleroptila shelleyi, Syrmaticus ellioti, Syrmaticus humiae, Syrmaticus mikado, Syrmaticus reevesii, Syrmaticus soemmerringii, Tetrao urogalloides, Tetrao urogallus, Tetraogallus himalayensis, Tetrastes bonasia, Tragopan caboti, Tragopan satyra, Tragopan temminckii, Tympanuchus cupido, Tympanuchus phasianellus. In addition, skulls of Macrocephalon maleo and Oreophasis derbianus were examined based on photographs of specimens in the Museum für Naturkunde, Berlin (Germany), and the Natural History Museum, Tring (UK), respectively. Comparisons with Leipoa ocellata and Aepypodius arfakianus (both Megapodiidae) are based on illustrations in Zusi and Livezey (2000) and Weber (1996).

Like other fossils from the Makah Formation, the skull was encased in a calcareous concretion. The latter was split by the collector and glued together before the matrix was dissolved with a $4 \%$ solution of formic acid buffered with tricalcium phosphate.

For micro-computed tomography $(\mu \mathrm{CT})$, the specimen was scanned at the Senckenberg CT-Lab Frankfurt/Main with the ProCon-X-Ray-Micro-CT with a $100 \mathrm{kV}$ Finefocus tube. The scans were performed with $90 \mathrm{kV}$ and $89 \mu \mathrm{A}$, generating 1600 projections (endocast reconstruction) and 2400 projections (surface reconstruction) with $1500 \mathrm{~ms}$ per scan. To increase the signal to noise ratio, 3 exposures per image were averaged. While recording, the ring artefact reduction mode was applied (projection on different areas of the X-ray detector for each image). The resolution (voxel size) was 19.41 and $20.49 \mu \mathrm{m}$, respectively. The data sets were segmented and visualized with VGStudio MAX, version 3.4 (Volume Graphics, Heidelberg, Germany).

\section{Systematic paleontology}

Aves Linnaeus, 1758.

Galliformes Temminck, 1820.

Gen. et sp. indet.

\section{Referred specimen}

SMF Av 666: partial cranium (Fig. 1a-d).

\section{Locality and horizon}

Beach terrace approximately $320 \mathrm{~m}$ northwest of the mouth of Jansen Creek, south shore of the Strait of Juan de Fuca, Clallam County, Washington State, USA $\left(48.32665^{\circ} \mathrm{N}\right.$, $\left.124.47338^{\circ} \mathrm{W}\right)$; Jansen Creek Member of the Makah Formation, latest Eocene or earliest Oligocene; collected by Terry Iversen on 16th June 2017.

\section{Measurements (in mm)}

Length as preserved, 37.5; estimated total length of complete skull (assuming a beak with galliform-like proportions), 55-60; width across processus postorbitales, 25.7; width of nasofrontal hinge, 13.3.

\section{Description and comparisons}

The specimen consists of a cranium lacking the palatal bones as well as the rostrum, broken away at the nasofrontal hinge. As indicated by the completely co-ossified sutura 

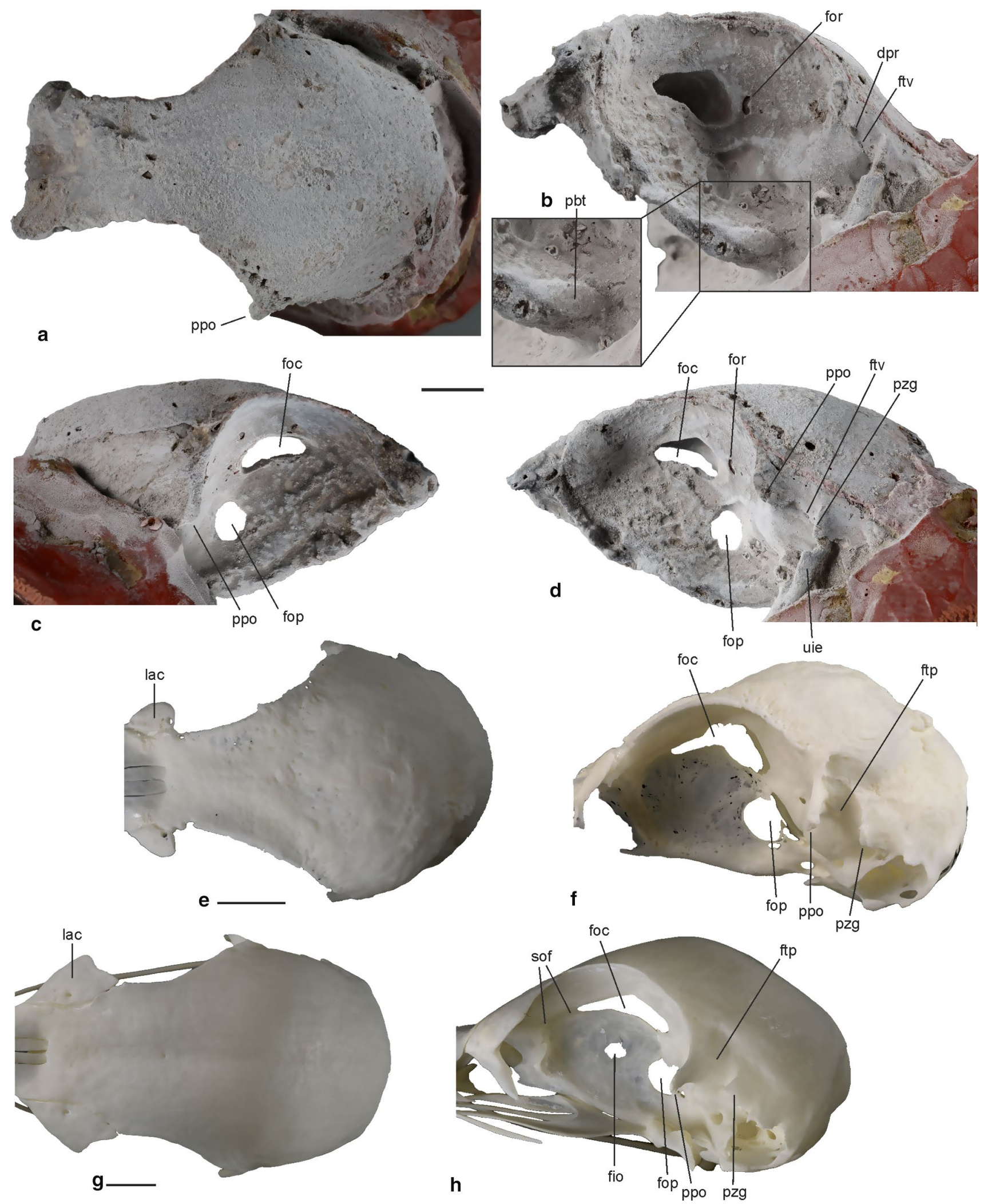
4Fig. 1 a-d Cranium of a galliform bird (SMF Av 666) from the latest Eocene or early Oligocene Jansen Creek Member of the Makah Formation, Washington State, USA, in a dorsal, b rostrolateral, $\mathbf{c}$ right lateral, and $\mathbf{d}$ left lateral view; the caudal portion of the specimen is attached to synthetic resin (red color). e, $\mathbf{f}$ Cranium of the extant Arborophila brunneopectus (Phasianidae; SMF 14588) in e dorsal and $\mathbf{f}$ left lateral view. $\mathbf{g}, \mathbf{h}$ Cranium of the extant Ortalis canicollis (Cracidae; SMF 14247) in $\mathbf{g}$ dorsal and $\mathbf{h}$ left lateral view. $d p r$ pitlike depression rostral to foramen temporale venosum, fio fonticulus interorbitalis, foc fonticulus orbitocranialis, fop foramen opticum, for kidney-shaped foramen caudal of fonticulus orbitocranialis, $f t p$ fossa temporalis, ftv foramen temporale venosum, lac lacrimal, $p b t$ processus basipterygoideus, ppo processus postorbitalis, $p z g$ processus zygomaticus, sof sulcus olfactorius, uie unidentified element. The fossil specimen was coated with ammonium chloride. The scale bars equal $5 \mathrm{~mm}$. [Color online]

frontoparietalis, it is from an adult bird (fissures along the dorsolateral surfaces represent cracks owing to the fact that the fossil was fractured in the discovery process). Because skulls of other Paleogene galliforms, that is, the gallinuloidid taxa Paraortygoides and Gallinuloides and the phasianoidean taxon Palaeortyx, are too poorly preserved for detailed comparisons, the following description is mainly based on comparisons with crown group Galliformes.

The fossil agrees well with the skulls of some crown group Galliformes in proportions and morphological features (Fig. 1). No traces of an ectethmoid can be discerned, but the corresponding area is not well preserved (the ectethmoid is well developed in the Megapodiidae but reduced in the Cracidae and Phasianidae). Likewise, there are no well-defined articular facets for the lacrimals (in the Cracidae, the caudal portion of the lacrimal articulates with the frontal and is attached to the orbital rim; Fig. 1g).

Unlike in the Megapodiidae, the fonticulus orbitocranialis is well developed; in contrast to the Cracidae (Fig. 1h), there is no laterally open sulcus olfactorius. On the left side of the specimen, a kidney-shaped foramen is located caudal of the fonticulus orbitocranialis (Figs. 1d, 2g); this foramen is not present on the right side of the fossil. A fonticulus interorbitalis is absent. The large foramen opticum is similar in size and position to the foramen of crown group Galliformes.

The interorbital section formed by the frontal bones is mediolaterally narrow and measures only about one third of the maximum width of the skull. The interorbital section is equally narrow in many taxa of the Phasianidae (Fig. 1e), whereas it is wider in the Megapodiidae, Cracidae (Fig. 1g), and Numididae. The cranium has a sub-cylindrical shape and its dorsal surface is not as vaulted as it is in most crown group Galliformes. An equally flat dorsal surface of the cranium is found in the phasianid taxa Ammoperdix and Alectoris. Cross sectional images generated by micro-CT scans show that the bone walls of the dorsal portion of the neurocranium are very thick in the area of the parietals, as they are in at least some crown group Galliformes (only a cross section of the skull of Gallus gallus was available to us), whereas the skull roof of the fossil has thinner bone walls than G. gallus in the area of the frontals (Fig. 3a-d).

As in other galliforms, the processus postorbitalis is a laterally protruding, subtriangular projection rather than a rod-shaped process. In the fossil, the tip of the right processus postorbitalis is broken, whereas the left one is complete. The lateral margin of the processus postorbitalis forms a ridge, as it does in many crown group Galliformes.

Overall, the morphology of the temporal region of the fossil (Fig. 4a) is most similar to that of extant Arborophila (Fig. 4g), which is one of the earliest diverging taxa of the Phasianidae (Wang et al. 2013). The processus zygomaticus is a dorsoventrally oriented, flange-like embossment, and there is no indication of an ossified aponeurosis zygomatica (Fig. 4f, i), which characterizes many crown group Galliformes (Zusi and Livezey 2000; Elzanowski and Mayr 2018). An ossified aponeurosis zygomatica evolved multiple times within crown group Galliformes (see discussion) and is absent in the early Eocene stem group galliform Gallinuloides (Mayr and Weidig 2004) and the Oligocene Palaeortyx (Mayr et al. 2006), which is an early diverging representative of the Phasianoidea. A short processus suprameaticus is visible on the left side of the fossil, immediately caudal of the cotyla quadratica squamosi (of which only the lateral rim is exposed). Unfortunately, the tip of this process is broken, so we cannot determine whether it contributed to an osseous bridge delimiting the cranial margin of the tympanic cavity, as it does in many crown group Odontophoridae (except Ptilopachus; Fig. 4e) and Phasianidae (including Arborophila; Fig. 4g).

As in most extant Galliformes, the fossa temporalis is poorly developed. Furthermore, as in crown group Galliformes, there is a small vascular foramen in this fossa, between the processus postorbitalis and the processus zygomaticus (Fig. 4; see discussion). This foramen is of similar size and position to the foramen in crown group Galliformes and is macroscopically visible (Fig. 4a). Owing to the fact that it is infilled by sediment of similar density to the bone, the foramen is not well delimited in the surface model created by micro-CT data (Fig. 2h), even though cross sectional images of this area show a canal that passes into the brain cavity (Fig. 2j). Unlike in extant galliform birds, the fossil exhibits a marked, pit-like depression rostral to this foramen (Figs. 2h, 4a).

The rostrum parasphenoidale exhibits rostrocaudally elongate and sessile processus basipterygoidei (Figs. 1b, 2f), a derived character of galloanserine birds. In the fossil, the articular facets of these processes are poorly developed, which is especially true for the right one that appears to be eroded. Other features of the basicranium, as well as details of the otic region, are not preserved in the fossil. 

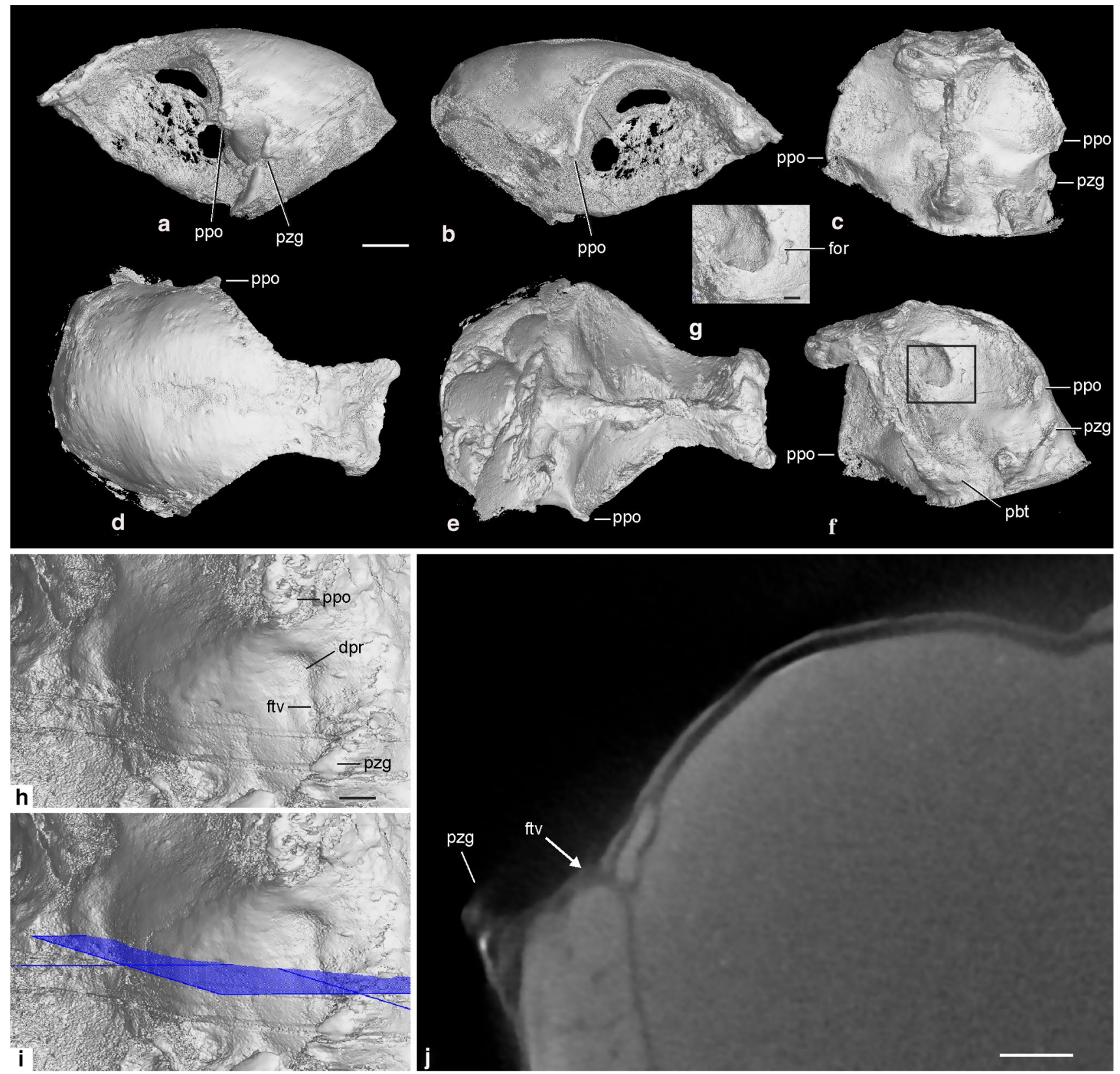

Fig. 2 a-g Micro-CT scans of the fossil cranium (SMF Av 666) in a left lateral, b right lateral, c cranial, d dorsal, e ventral, and $\mathbf{f}$ rostrolateral view; $\mathbf{g}$ shows a detail of the framed area in $\mathbf{f}$. $\mathbf{h}-\mathbf{j}$ Detail of temporal region with transverse section on the level of the foramen temporale venosum; in $\mathbf{i}$, the plane of the section is shown. $d p r$

An elongate element situated next to the left otic region (Fig. 1d) cannot be identified. This structure may be mistaken for an ossified aponeurosis zygomatica, but in contrast to the latter, it is not flattened and sheet-like but tubular. The apparent bifurcation of this element and its clear separation from the processus zygomaticus furthermore preclude its identification as an ossified aponeurosis zygomatica. Judging from its slightly darker color, it may not be bone but a pit-like depression rostral to foramen temporale venosum, for kidneyshaped foramen caudal of fonticulus orbitocranialis, $f t v$ foramen temporale venosum, pbt processus basipterygoideus, ppo processus postorbitalis, $p z g$ processus zygomaticus. Scale bar equals $5 \mathrm{~mm}$ in $\mathbf{a}-\mathbf{f}$ and $1 \mathrm{~mm}$ in $\mathbf{g}-\mathbf{j}$. [Color online]

small piece of wood; fossilized wood is occasionally found together with avian remains in the Makah Formation.

The virtual cranial endocast (Fig. 5a, b) exhibits a morphology similar to that of extant Megapodiidae and Phasianidae (Fig. 5c-f; Handley and Worthy 2021, see also Early et al. 2020). As in the latter, the shapes of the two telencephalic hemispheres give the rostral portion of the endocast a heart-shaped outline in dorsal and ventral view. In addition, 

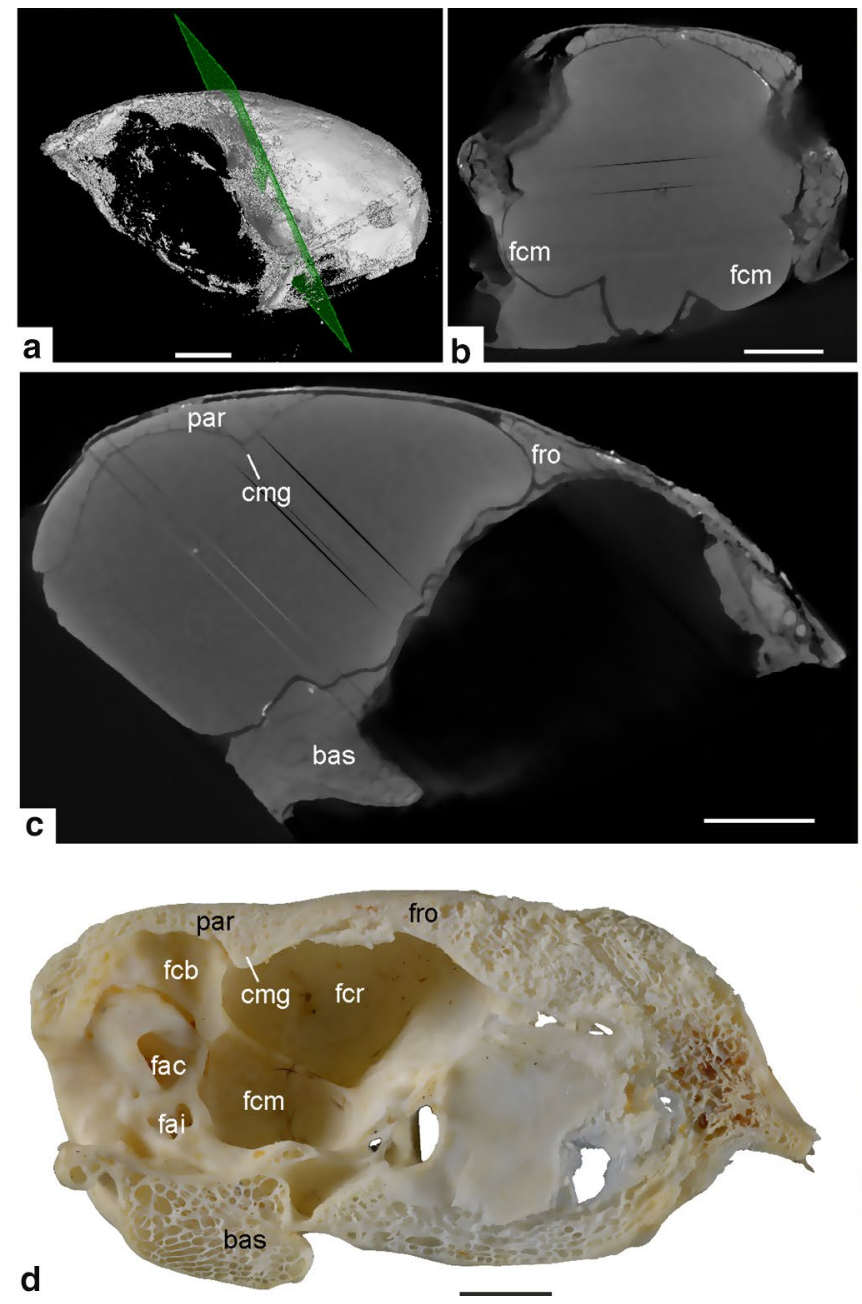

Fig. 3 a-c Virtual sections through the fossil skull based on microCT data (b: frontal section, c: longitudinal section; in a, the plane is indicated, in which the frontal section was taken); the striations are scanning artefacts. d Longitudinal section of the cranium of the extant Gallus gallus (Phasianidae; SMF, uncatalogued). e Cast of wing and pectoral girdle bones of an undescribed galliform fossil from the Jansen Creek Member of the Makah Formation east of Neah

as in crown group Galliformes, the wulsts are weakly developed. The mesencephalon (optic lobe) and cerebellum are likewise of similar shape and size to the corresponding brain parts of crown group Galliformes. Whereas there was a clear differentiation between the bones and the rostral portion of the endocast (telencephalic hemispheres) in the micro-CT scans, no unambiguous distinction between bone and surrounding matrix was possible in the area of the flocculus and our reconstruction of the shape of the latter structure is tentative. The bulbus olfactorius is not completely preserved.

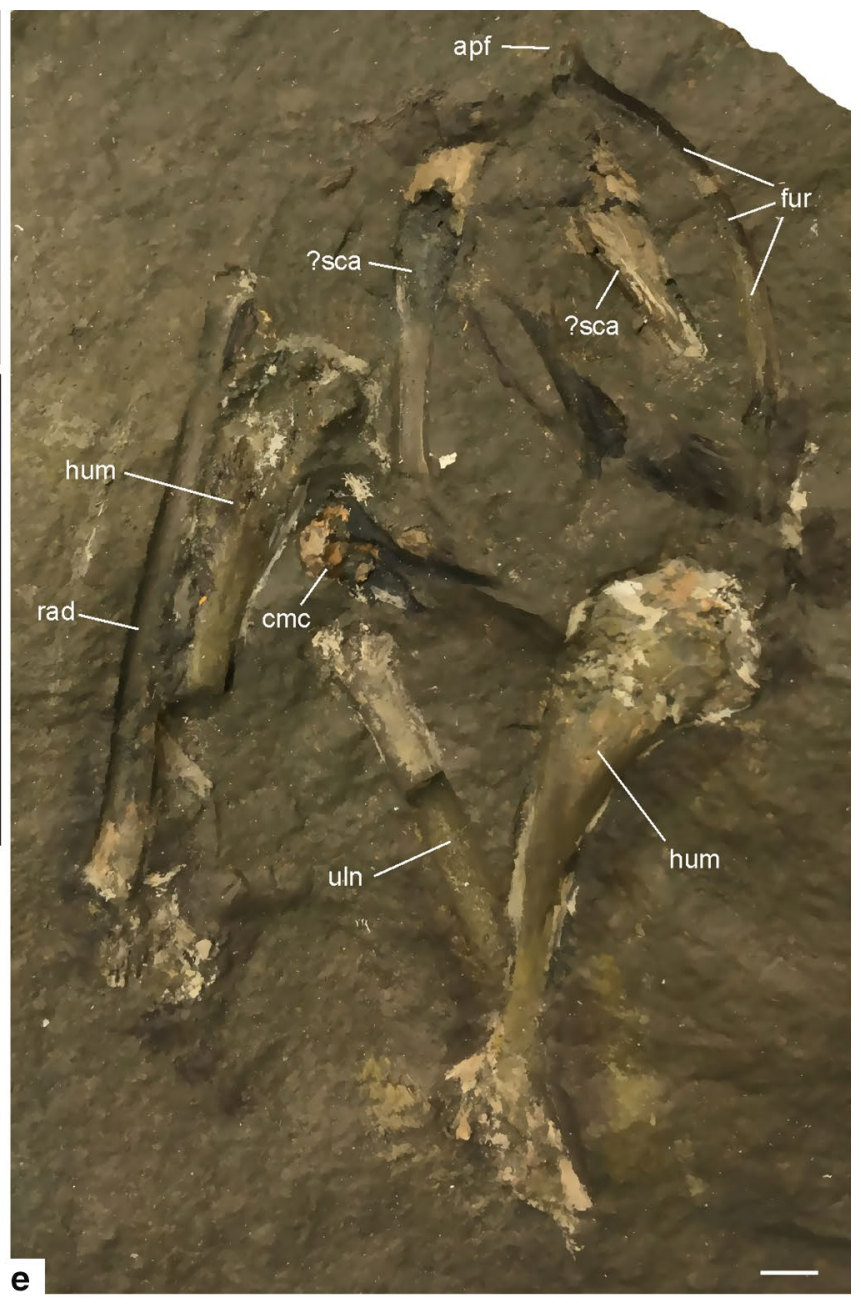

Bay (UWBM 88804-C1009). apf apophysis furculae, bas basicranium, $\mathrm{cmc}$ carpometacarpus, $\mathrm{cmg}$ crista marginalis, fac fossa auriculae cerebelli, fai fossa acustica interna, $f c b$ fossa cerebelli, $f c m$ fossa cranii media, $f c r$ fossa cranii rostralis, fro frontal, fur furcula, hum humerus, par parietal, rad radius, sca scapula, uln ulna. The scale bars equal $5 \mathrm{~mm}$. [Color online]

\section{Discussion}

SMF Av 666 exhibits sessile basipterygoid processes, which are an apomorphy of galloanserines. The vascular foramen in the temporal fossa, between the postorbital and zygomatic processes, represents a distinctive autapomorphy of at least crown group galliforms, which has not been mentioned in earlier works on the galliform skull (e.g., Parker 1869; Jollie 1957) or more recent treatises of avian anatomy (e.g., Gheţie 1976; Baumel et al. 1993). It is identical to the "middle meningeal foramen" of Sedlmayr (2002: 182) and Porter and Witmer (2016: 1474) and opens into the skull cavity, being situated at the boundary between the squamosal and the laterosphenoid (Fig. 4h). The foramen enables the vena profunda to communicate between the ophthalmic rete and 

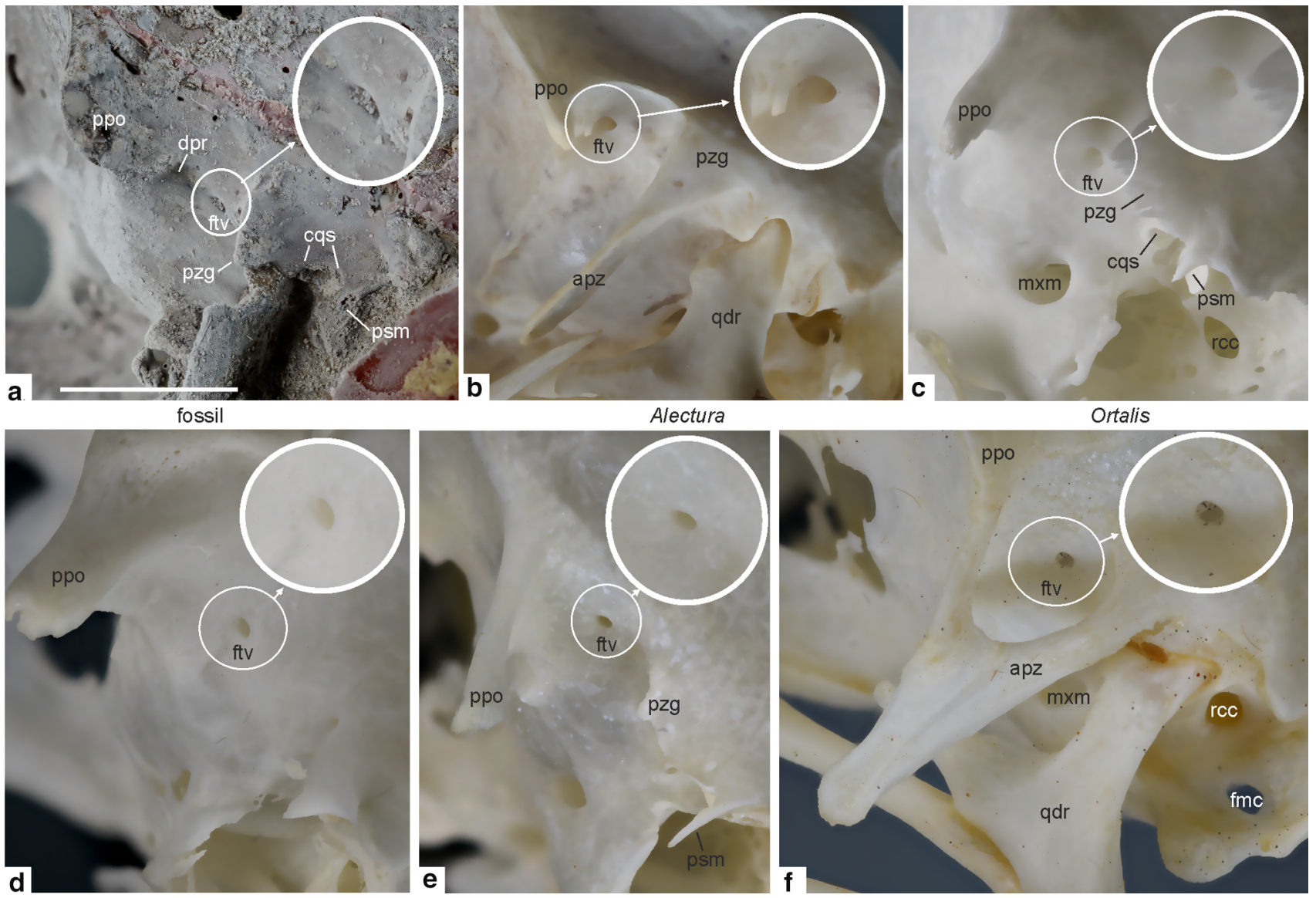

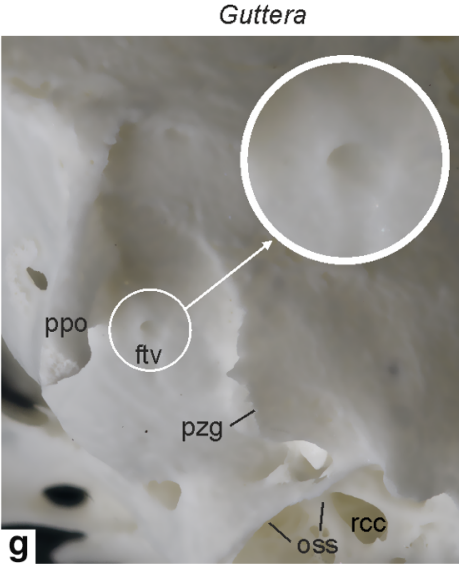

Arborophila

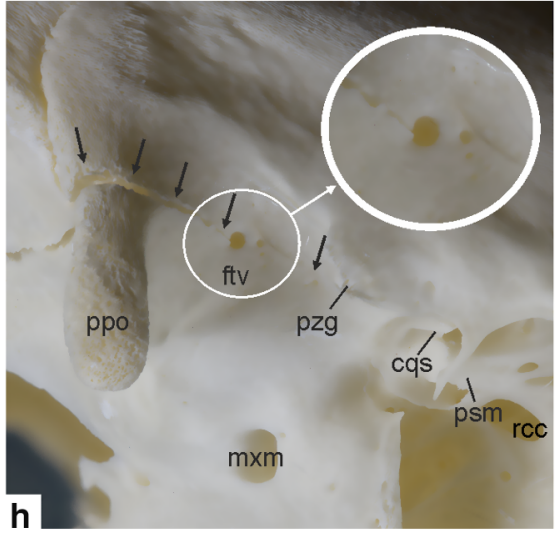

Pavo (juv.)

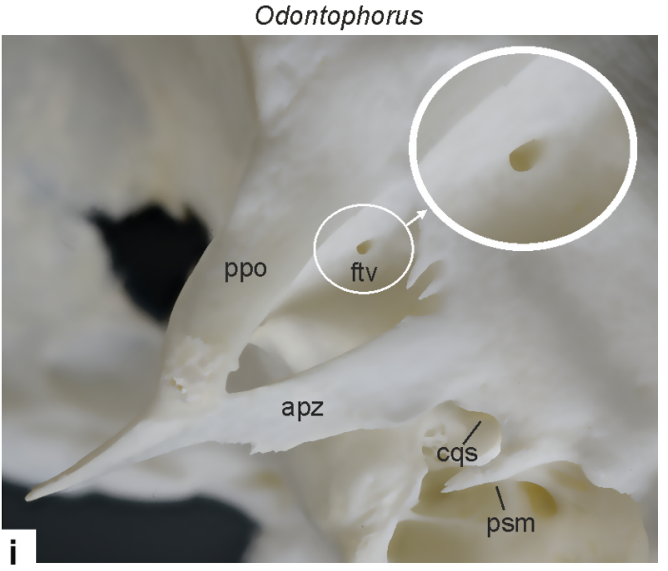

Pavo
Fig. 4 Temporal region of the fossil from the Makah Formation (SMF Av 666) and extant Galliformes in lateral view; encircled areas show magnified details of the foramen temporale venosum. Species without an ossified aponeurosis zygomatica are overrepresented in this figure. a SMF Av 666 (coated with ammonium chloride). b Alectura lathami (Megapodiidae; SMF 14285). c Ortalis canicollis (Cracidae; SMF 14247). d Guttera edouardi (Numididae; SMF 14283). e Ptilopachus petrosus (Odontophoridae; SMF 14593). f Odontophorus capueira (Odontophoridae; SMF 19671). g Arborophila brunneopectus (Phasianidae; SMF 14588). h Juvenile Pavo crista- tus (Phasianidae; SMF 14309); arrows indicate the suture between the squamosal and the laterosphenoid. i Adult $P$. cristatus (SMF 14306). $a p z$ ossified aponeurosis zygomatica, cqs cotyla quadratica squamosi, $d p r$ pit-like depression rostral to foramen temporale venosum, $f m c$ foramen musculi columellae, $f t v$ foramen temporale venosum, $m x m$ foramen nervi maxillomandibularis, oss osseous bridge delimiting the cranial margin of the tympanic cavity, ppo processus postorbitalis, $p s m$ processus suprameaticus, $p z g$ processus zygomaticus, $q d r$ quadrate, $r c c$ recessus columellae. Scale bar in a represents $5 \mathrm{~mm}$, images of extant taxa not to scale. [Color online] 


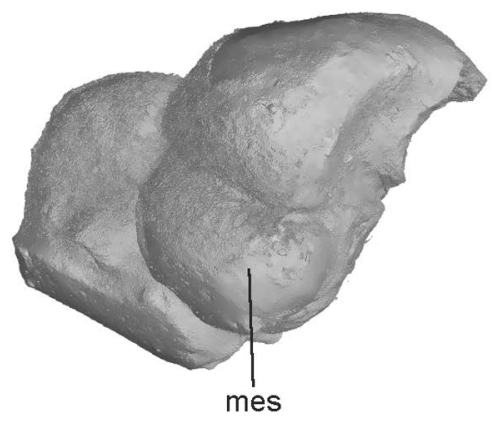

a

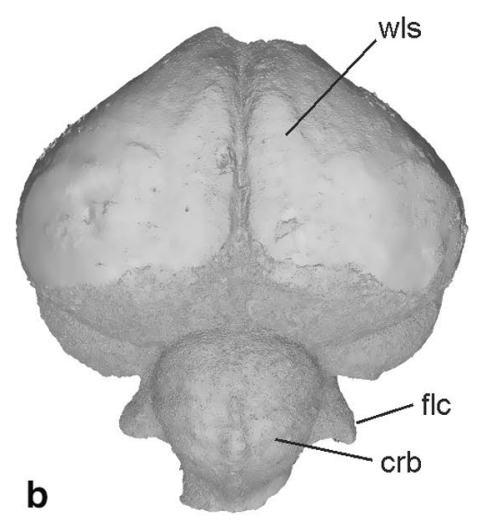

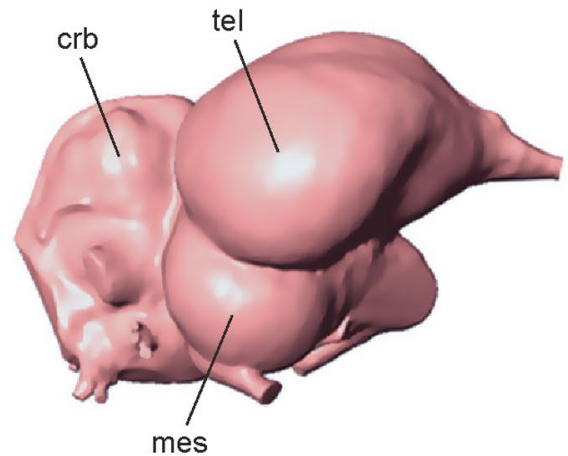

C

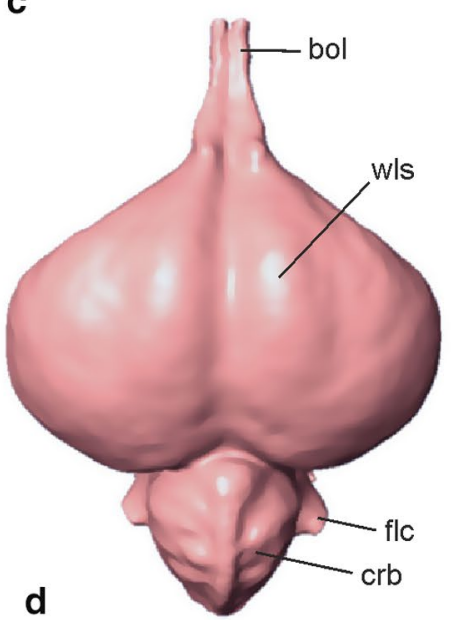

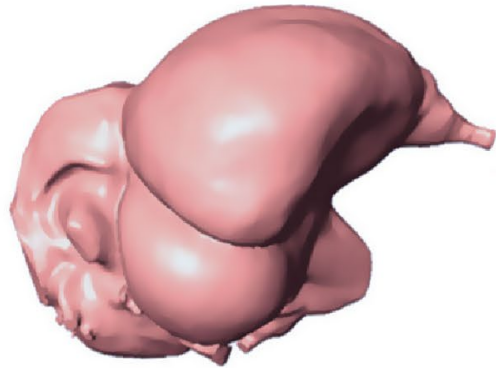

e

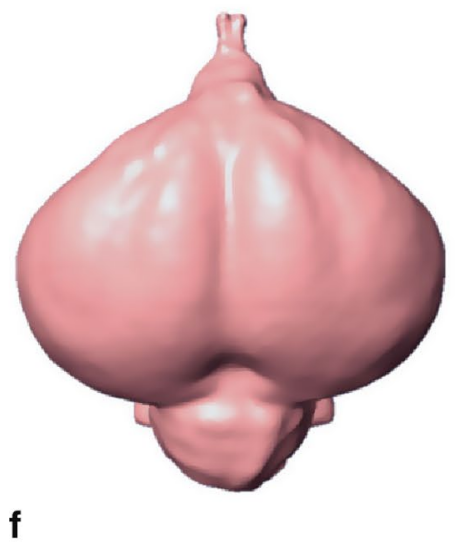

Fig. 5 Virtual cranial endocasts of SMF Av 666 (a, b) and extant Galliformes (c-f). a, b Endocast of SMF Av 666 in lateral and dorsal view. c-f Endocasts of c, $\mathbf{d}$ the extant Leipoa ocellata (Megapodiidae) and $\mathbf{e}, \mathbf{f}$ Gallus gallus (Phasianidae) in lateral and dorsal view (from Handley and Worthy 2021; published under a Creative Com- mons CC BY 4.0 license). bol bulbus olfactorius, $c r b$ cerebrum, $f l c$ flocculus, mes mesencephalon (optic lobe), tel telencephalon, wls wulst. Scale bar equals $5 \mathrm{~mm}$ in $\mathbf{a}$ and $\mathbf{b}$, images in $\mathbf{c}-\mathbf{f}$ are not to scale. [Color online]

immediate physiological significance of the foramen is not apparent. However, galliforms exhibit other derived characteristics of the vascular system of the skull and, for example, lack the occipital ramus of arteria ophthalmica externa, with the latter artery supplying the ophthalmic rete (Mayr 2020). Because the ophthalmic rete plays a role in thermoregulation, a functional correlation may exist between the foramen temporale venosum and integumentary features, such as naked skin parts or wattles, even though there appears to be no obvious correlation between the size of the foramen and the aforementioned structures. A determination of the physiological significance of the foramen temporale venosum is certainly a promising venue for future studies, which also need to assess a possible functional interdependence of some autapomorphic vascular characters in the skull of galliforms.

Future studies will also have to show when exactly a foramen temporale venosum evolved in the stem lineage of galliform birds, that is, whether it is an apomorphy of crown group Galliformes or whether it is present in some taxa of 
the stem lineage. Currently, skulls of Cenozoic stem group galliforms are only known from the Gallinuloididae (Mayr and Weidig 2004) and Sylviornithidae (Mourer-Chauviré and Balouet 2005; see Mayr 2011 and Worthy et al. 2016 for the presumed stem group position of this taxon). However, it is not possible from the published photographs to assess the occurrence of a foramen temporale venosum in these birds and direct examinations of the fossils are required for firm conclusions about the presence or absence of this foramen in the above taxa.

The fossil (SMF Av 666) is from a species the size of a female Common Pheasant, Phasianus colchicus. In its size, it would correspond to the late Eocene and early Oligocene Procrax brevipes, Archaealectrornis sibleyi, and Palaeonossax senectus from Nebraska and South Dakota (see introduction), but because the skulls of these species are unknown, a species-level assessment of SMF Av 666 is not possible.

Whereas Procrax and Palaeonossax were likened to the Cracidae by earlier authors, various late Eocene and early Oligocene taxa from Europe clearly represent stem group Galliformes (Mayr 2009). With the phasianoid taxon Palaeortyx, however, the first unambiguous crown group Galliformes likewise occur in the early Oligocene of Europe. From an evolutionary and biogeographic point of view, it is therefore of interest whether galliforms from coeval North America faunas represent stem or crown group taxa.

In the stem group galliform taxon Gallinuloididae and in extant Megapodiidae, the ectethmoid bone is well developed. Presumably, this represents the plesiomorphic condition for Galliformes, because a well-developed ectethmoid is found in most non-galliform neognathous birds. A reduced ectethmoid bone would suggest a position of SMF Av 666 in the galliform crown group, within a clade formed by the Cracidae and Phasianoidea. However, the corresponding area of the fossil is not well preserved, and we cannot exclude the possibility that the ectethmoid is broken away. Other osteological characters visible in SMF Av 666 do not allow an unambiguous assignment to the galliform stem or crown group.

Galliform and anseriform birds are characterized by a short or completely reduced processus zygomaticus (Zusi and Livezey 2000). In most extant Galliformes, an ossified aponeurosis zygomatica inserts on the short processus zygomaticus, which often co-ossifies with the postorbital process to form an orbitozygomatic junction. This junction evolved independently in some Cracidae, all Odontophoridae except for Ptilopachus (which was long assigned to the Phasianidae, but is now recovered as an Old World representative of the Odontophoridae; Cohen et al. 2012), and many Phasianidae (Elzanowski and Mayr 2018).
Ossification of the zygomatic aponeurosis occurs in postnatal development (Zusi and Livezey 2000; Elzanowski and Mayr 2018), and among the extant galliform species studied, an ossified aponeurosis zygomatica is absent in adult individuals of Macrocephalon (Megapodiidae), some Cracidae (Ortalis, Oreophasis), all Numididae, as well as Ptilopachus (which is the sister taxon of New World Odontophoridae; Cohen et al. 2012) and Arborophila (which, together with Rollulus and Caloperdix, is one of the earliest diverging taxa of the Phasianidae; Wang et al. 2013). As noted in the description, an ossified aponeurosis zygomatica is absent in the early Eocene stem group galliform Gallinuloides and in the Oligocene phasianoidean taxon Palaeortyx (Mayr and Weidig 2004; Mayr et al. 2006). Most likely, therefore, the absence of an ossified aponeurosis zygomatica is plesiomorphic for crown group Galliformes and this character evolved multiple times independently, in the Megapodiidae, Cracidae, Odontophoridae, and Phasianidae. Functionally, this variation of the temporal region may be correlated with different feeding strategies of galliform birds, even though comparative functional morphological studies still have to be performed.

The absence of an ossified aponeurosis zygomatica in SMF Av 666 is also likely to be a plesiomorphic trait. With regard to the morphology of the temporal region, in particular the shape of the processus zygomaticus, the fossil most closely resembles the Asian Arborophila (Phasianidae), with which it also agrees well in the overall shape of the cranium (Fig. 1). We consider it possible that the fossil represents an archaic member of the Phasianoidea, in which case it would be the earliest record of this taxon from the New World. However, we note that most similarities to Arborophila are plesiomorphic and it is not possible to unambiguously constrain the affinities of the fossil with derived characters.

As long as the affinities between SMF Av 666 and the coeval North American taxa Procrax, Palaeonossax, and Archaealectrornis are not better constrained, a robust phylogenetic placement of the new fossil is not possible. At least Procrax brevipes lacks derived characteristics of the Phasianoidea, such as a well-developed intermetacarpal process (carpometacarpus), and Archaealectrornis is likely to even be outside crown group Galliformes (Mayr 2009).

Further light on the affinities of SMF Av 666 may be shed by another fossil from the Jansen Creek Member of the Makah Formation east of Neah Bay (Washington State), of which only a cast is available (UWBM 88804-C1009). The original unprepared specimen was in a private collection but its current whereabouts are unknown. It consists of wing and pectoral girdle bones in a split nodule and- - judging from the shapes of the humerus and furcula as well as 
the short ulna-appears to represent a galliform (Fig. 3e). With a humerus length of approximately $56 \mathrm{~mm}$, it is from a species that was smaller than Procrax brevipes $(79 \mathrm{~mm}$; Tordoff and MacDonald 1957) and Archaealectrornis sibleyi (77.3 mm; Crowe and Short 1992). Palaeonossax senectus is only known from the distal end of the humerus, which is not well exposed in UWBM 88804-C1009 making meaningful size comparisons impossible. The furcula of UWBM 88804-C1009 is more strongly U-shaped that that of crown group Galliformes (which is V-shaped) and the apophysis furculae is proportionally smaller than in most extant galliform species. It is not possible to reliably assess the affinities of the fossil from a study of the cast alone, because critical parts of the bones are not exposed. Still, we are confident that if a future examination of the original fossil eventually becomes possible, it will contribute to a better understanding of the phylogenetic affinities of Eocene and Oligocene North American galliforms.

Acknowledgements We are indebted to Terry Iversen (Bremerton, Washington) for discovery and collection of the fossil specimen and donating it to SMF. Olaf Vogel (SMF) is thanked for its preparation. The photos were made by Sven Tränkner (SMF). Lawrence Witmer and Ruger Porter are thanked for confirming the identification of the temporal foramen as the structure they termed "middle meningeal foramen". Christian Sidor and Katie Anderson (UWBM) enabled the study of fossil specimens in UWBM. Comments from two anonymous reviewers improved the manuscript.

Funding Open Access funding enabled and organized by Projekt DEAL.

Open Access This article is licensed under a Creative Commons Attribution 4.0 International License, which permits use, sharing, adaptation, distribution and reproduction in any medium or format, as long as you give appropriate credit to the original author(s) and the source, provide a link to the Creative Commons licence, and indicate if changes were made. The images or other third party material in this article are included in the article's Creative Commons licence, unless indicated otherwise in a credit line to the material. If material is not included in the article's Creative Commons licence and your intended use is not permitted by statutory regulation or exceeds the permitted use, you will need to obtain permission directly from the copyright holder. To view a copy of this licence, visit http://creativecommons.org/licenses/by/4.0/.

\section{References}

Baumel JJ, King AS, Breazile JE, Evans HE, Vanden Berge JC (1993) Handbook of avian anatomy: nomina anatomica avium, 2nd edn, vol 23. Nuttall Ornithological Club, Cambridge, MA, pp 1-779

Cohen C, Wakeling JL, Mandiwana-Neudani TG, Sande E, Dranzoa C, Crowe TM, Bowie RC (2012) Phylogenetic affinities of evolutionarily enigmatic African galliforms: the Stone Partridge Ptilopachus petrosus and Nahan's Francolin Francolinus nahani, and support for their sister relationship with New World quails. Ibis 154:768-780

Crowe TM, Short LL (1992) A new gallinaceous bird from the Oligocene of Nebraska, with comments on the phylogenetic position of the Gallinuloididae. In: Campbell KE (ed) Papers in Avian Paleontology honoring Pierce Brodkorb, vol 36. Natural History Museum of Los Angeles County Science Series, pp 179-185

Early CM, Ridgely RC, Witmer LM (2020) Beyond endocasts: using predicted brain-structure volumes of extinct birds to assess neuroanatomical and behavioral inferences. Diversity 12(1):34

Elzanowski A, Mayr G (2018) Multiple origins of secondary temporal fenestrae and orbitozygomatic junctions in birds. J Zool Syst Evol Res 56:248-269

Gheţie V (1976) Atlas de anatomie a păsărilor domestice [Anatomical atlas of domestic birds]. Editura Acadimei republicii Socialiste România, Bucharest

Goedert JL, Cornish J (2002) A preliminary report on the diversity and stratigraphic distribution of the Plotopteridae (Pelecaniformes) in Paleogene rocks of Washington State, USA. In: Zhou Z, Zhang F (eds) Proceedings of the 5th Symposium of the Society of Avian Paleontology and Evolution, Beijing, 1-4 June 2000. Science Press, Beijing, pp 63-76

Handley WD, Worthy TH (2021) Endocranial anatomy of the giant extinct Australian Mihirung birds (Aves, Dromornithidae). Diversity 13(3): 124

Jollie MT (1957) The head skeleton of the chicken and remarks on the anatomy of this region in other birds. J Morphol 100:389-436

Kilgore DL, Bernstein MH, Hudson DM (1976) Brain temperatures in birds. J Comparat Physiol B Biochem Syst Environ Physiol 110:209-215

Mayr G (2009) Paleogene fossil birds. Springer, Heidelberg

Mayr G (2011) Cenozoic mystery birds - on the phylogenetic affinities of bony-toothed birds (Pelagornithidae). Zool Scr 40:448-467

Mayr G (2015) A procellariiform bird from the early Oligocene of North America. N Jb Geol Paläontol, Abh 275:11-17

Mayr G (2020) The otic region of the skull of neognathous birds: on the homology and comparative morphology of some neurovascular and muscular foramina and other external skeletal structures. Vertebr Zool 70:69-85

Mayr G, Weidig I (2004) The early Eocene bird Gallinuloides wyomingensis - a stem group representative of Galliformes. Acta Palaeontol Polon 49:211-217

Mayr G, Goedert JL (2016) New late Eocene and Oligocene remains of the flightless, penguin-like plotopterids (Aves, Plotopteridae) from western Washington State USA. J Vertebr Paleontol 36:e1163573

Mayr G, Goedert JL (2018) First record of a tarsometatarsus of Tonsala hildegardae (Plotopteridae) and other avian remains from the late Eocene/early Oligocene of Washington State (USA). Geobios 51:51-59

Mayr G, Poschmann M, Wuttke M (2006) A nearly complete skeleton of the fossil galliform bird Palaeortyx from the late Oligocene of Germany. Acta Ornithol 41:129-135

Mayr G, Goedert JL, Vogel O (2015) Oligocene plotopterid skulls from western North America and their bearing on the phylogenetic affinities of these penguin-like seabirds. J Vertebr Paleontol 35:e943764

Mayr G, Goedert JL (2021) New late Eocene and Oligocene plotopterid fossils from Washington State (USA), with a revision of "Tonsala" buchanani (Aves, Plotopteridae). J Paleontol In press

Midtgård U (1983) Scaling of the brain and the eye cooling system in birds: a morphometric analysis of the rete ophthalmicum. J Experiment Zool A Ecol Genet Physiol 225:197-207

Midtgård U (1984) The blood vascular system in the head of the herring gull (Larus argentatus). J Morphol 179:135-152

Mourer-Chauvire C, Balouet JC (2005) Description of the skull of the genus Sylviornis Poplin, 1980 (Galliformes, Sylviornithidae new family), a giant extinct bird from the Holocene of New Caledonia. Monogr Soc Hist Nat Balears 12:205-218 
Parker WK (1869) XXIX. On the structure and development of the skull of the common fowl (Gallus domesticus). Phil Trans Roy Soc Lond 159:755-807

Porter WMR, Witmer LM (2016) Avian cephalic vascular anatomy, sites of thermal exchange, and the rete ophthalmicum. Anat Rec 299:1461-1486

Sedlmayr JC (2002) Anatomy, evolution, and functional significance of cephalic vasculature in Archosauria. Unpublished $\mathrm{PhD}$ dissertation, Ohio University, Athens, Ohio

Stidham TA, Townsend KE, Holroyd PA (2020) Evidence for wide dispersal in a stem galliform clade from a new small-sized middle Eocene pangalliform (Aves: Paraortygidae) from the Uinta Basin of Utah (USA). Diversity 12(3):90

Tordoff HB, MacDonald JR (1957) A new bird (family Cracidae) from the early Oligocene of South Dakota. Auk 74:174-184

Wang N, Kimball RT, Braun EL, Liang B, Zhang Z (2013) Assessing phylogenetic relationships among Galliformes: a multigene phylogeny with expanded taxon sampling in Phasianidae. PLoS ONE 8(5):e64312

Weber E (1996) Das Skelet-Muskel-System des Kieferapparates von Aepypodius arfakianus (Salvadori, 1877) (Aves, Megapodiidae). Cour Forsch-Inst Senckenberg 189:1-130
Weigel RD (1963) Oligocene birds from Saskatchewan. Q J Fla Acad Sci 26:257-262

Wetmore A (1956) A fossil guan from the Oligocene of South Dakota. Condor 58:234-235

Worthy TH, Mitri M, Handley WD, Lee MS, Anderson A, Sand C (2016) Osteology supports a stem-galliform affinity for the giant extinct flightless bird Sylviornis neocaledoniae (Sylviornithidae, Galloanseres). PLoS ONE 11:e0150871

Zusi RL, Livezey BC (2000) Homology and phylogenetic implications of some enigmatic cranial features in galliform and anseriform birds. Ann Carnegie Mus 69:157-193

Publisher's Note Springer Nature remains neutral with regard to jurisdictional claims in published maps and institutional affiliations. 